\title{
LETTER 18
}

\section{PETER THE VENERABLE: A LETTER OF ABSOLUTION FOR ABELARD}

Background: The letter of absolution, together with the epitaphs for Abelard and Heloise were added in the late-fifteenth or early-sixteenth century to the last page of MS T, fol. $102 \mathrm{v}$, and also to Chaumont, Bibliothèque municipal, 31, fol. 245v, at the end of the fifteenth century, 2 May 1497, on the occasion of their removal from their original graves and their burial in the new church of abbess Catherine II de Courcelle. My translations of these texts are based on the editions of Charles S.F. Burnett and of Constant Mews in the appendix to "La bibliothèque du Paraclet du XIIIe siècle à la Révolution.” As Giles Constable notes in the exchange of letters between Peter the Venerable and Heloise, the distinction between letters patent and closed is stressed (Letters 2, p. 23). Peter has apparently sent the original absolution in a closed or sealed letter of which the seal was broken when it was opened. In Letter 167 [Letter 16 in this volume], Heloise asked for another sealed document containing the absolution of master Peter within an open letter to be placed in his tomb. In reply, Peter sent "written and sealed" the absolution of Peter Abelard together with a similarly "closed" grant of a trental or thirty days of prayer after her death for Heloise herself.

T, Peter, abbot of Cluny, who received Peter Abelard as a monk of Cluny, and secretly delivered his body to abbess Heloise and the nuns of the Paraclete, absolve him of all his sins by the authority of almighty God and the support of all the saints. Amen. 